\title{
On Rendering Wildness: Choices and Strategies for Translating John Muir's Essays into Italian
}

Notwithstanding its relevance and popularity around the world, the pioneering environmentalist work of John Muir (1838-1914) has strangely remained for the most part untranslated into Italian throughout the twentieth century. ${ }^{1}$ Only two volumes, among Muir's vast production, have in fact come out, and both in the last two decades, perhaps indicating that Muir's work and nature theorizations, pointed at gaining a "biocentric perspective of the world" (see Wilkins, 1995), sound more crucial today than they ever did before. However, there is still much work to be done, and so, when asked to translate a selection of his essays by the Prato-based publishing house PianoB, I gladly accepted. ${ }^{2}$

"I only went out for a walk, and finally concluded to stay out till sundown," Muir once wrote, "for going out, I found, was really going in" (see John of the Mountains: 439). Such sentiments well exemplify the core value of his

\footnotetext{
1 See, in chronological order: La mia prima estate sulla sierra; Mille miglia in cammino fino al golfo del Messico. The Roman publishing house Elliott is currently working at publishing, probably by the end of this year, an Italian translation of Muir's Travels in Alaska (1915).

2 Publication of the book with my translation, tentatively entitled Into the Wild. Appunti sulla natura selvaggia, is expected for December 2019. The selected texts are taken from Muir's The Mountains of California (1894); Our National Parks (1901); Travels in Alaska (1915); A Thousand-Mile Walk to the Gulf (1916); The Life and Letters of John Muir (1924); John of the Mountains: The Unpublished Journals of John Muir ([1938], 1979).
} 
writing method and message. Readers are taken out of their comfort zones into rough walks and invited to participate in often almost obsessively meticulous explorations of all that belongs to the sphere of nature: from animals to plants to bodies of water and soil. But by observing, through Muir's expert guiding words, the otherness of those outdoors, readers are asked to profoundly rethink themselves as individuals, the society that they are part of, and the customs of inhabiting the world, as defined and imposed by that society. The enactment of this radical critical introspection is strengthened and heightened by two fundamental components of Muir's writing: the use of a piercing irony that displays the absurdity and unfairness of many human assumptions and ways of living, and the presence of a lyrical and metaphysical breath that powerfully emerges, often unexpected, from the scientific, biological, and mathematical information.

In Muir's work, Thoreau's famous proclamation that “in Wildness is the preservation of the World" (see Thoreau, 1862) joins the equally famous lines by Fyodor Dostoevsky, "beauty will save the world" (see Dostoevsky, 1869); for Muir, wildness is beauty, and while its value and strength are explainable scientifically, they also remain inherently mysterious, not fully accessible by human knowledge. And if that wildness and beauty can save the world, they first of all need to be defended, preserved, and saved: Muir thus inaugurates a modern environmentalist agenda. Not only Thoreau's presence and influence can be detected in Muir's work, but more largely, that of American Transcendentalism fused with German Idealism and English romantic poetry. And Muir's tone and concepts of cosmic communion and sense of the value of every individual within a larger, universal belonging often echo Walt Whitman's work. For example, Muir writes: "The universe would be incomplete without man; but it would also be incomplete without the smallest transmicroscopic creature that dwells beyond our conceitful eyes and knowledge" (Muir, 1916). He also writes:

I have never yet happened upon a trace of evidence that seemed to show that any one animal was ever made for another as much as it was made for itself. Not that Nature manifests any such thing as a selfish isolation. In the making of every animal the presence of every other animal has been recognized. Indeed, every atom in creation may be said to be acquainted with and married to every other, but with universal union there is a division sufficient in degree for the purposes of the most intense individuality; no matter, therefore, what may be the note 
which any creature forms in the song of existence, it is made first for itself, then more and more remotely for all the world and worlds.

(Muir, 1875)

Muir's desire is to both illuminate, for readers, the contribution of each single component of nature's system to what he calls, Whitmanically, "the song of existence" and to represent and reverberate through his writing the innate beauty and harmony of this larger song. This comes close to Whitman's aspiration to portray the "every" and the "all," or the "every" in the "all."

There are a few main issues and challenges that I had to confront, as a translator, when working with Muir's nature essays. The first regards the syntax, which can often be laborious, due to the generally considerable length of the sentences, especially for English standards; the frequent cases of a slightly unusual - especially to modern ears - word order, employed to create an emphatic or poetic effect; and the accumulation of technical details and descriptive images of natural phenomena. This complexity and lack of fluidity is also accompanied by Muir's use of terms and expressions that can sound unusual and elevated, if not altogether archaic and obscure, to a twenty-first century ear, and by his references to the Bible and literary tradition. Let us observe, for example, this passage:

Furthermore, all uneatable and uncivilized animals, and all plants which carry prickles, are deplorable evils which, according to closes researches of clergy, require the cleansing chemistry of universal planetary combustion. But more than aught else mankind requires burning, as being in great part wicked, and if that transmundane furnace can be so applied and regulated as to smelt and purify us into conformity with the rest of the terrestrial creation, then the tophetization of the erratic genius Homo were a consummation devoutly to be prayed for. But, glad to leave these ecclesiastical fires and blunders, I joyfully return to the immortal truth and immortal beauty of Nature. ${ }^{3}$

The central sentence in this paragraph, "But more than aught else..." contains a series of peculiar traits of Muir's style that can be hard to render for a translator: from the archaism at the beginning of the sentence, to the long accumulation that describes the hypothetical scenario, to the reference to the

${ }^{3}$ John Muir, "Man's Place in the Universe," in A Thousand-Mile Walk to the Gulf. 
Hebrew Bible with "tophetization" (a term which evokes the Canaanites human sacrifice of their own children for the Gods, in the place just outside the walls of Jerusalem called Tophet, and which entered literary tradition as a synonym for hell). I tried to overcome the obstacles by rendering the central sentence as

Ma più di chiunque altro il genere umano abbisogna d'esser bruciato, essendo in gran parte cattivo, e se quella fornace transmondana si potesse far funzionare e regolare in modo da farci fondere e purificare fino a poter diventare conformi al resto della creazione terrestre, allora la tofetizzazione dell'incostante genio chiamato Homo sarebbe un atto per la cui realizzazione dovremmo pregare con devozione.

While I did not have a perfect equivalent for "aught else," in order to attempt to retain the tone I used the archaic verb "abbisognare" (instead of the modern form "aver bisogno") for "requires." I kept the accumulative and slightly intricate construction of the conditional phrase intact, and I also maintained "tophetization," accompanied by an explanatory footnote (that I think should be present also in recent English editions).

But this passage also presents one of the most difficult features to render for any translator, independently from genres, and across all languages: the use of irony, with its subtlety, playfulness, and reliance on readers' ability to infer the unsaid but hinted-at message thanks to resounding contextual references or even to slight changes in tone. It is clear, then, how Muir's essays are quite hard to translate, for they are saturated with irony. The beginning of "Wild Wool" is another fitting example of this, as it invokes readers' smiles right from the first line:

Moral improvers have calls to preach. I have a friend who has a call to plough, and woe to the daisy sod or azalea thicket that falls under the savage redemption of his keen steel shares.

The call to plough and enact a "savage redemption" are shown by Muir to be capable of reaching a whole, higher level of absurdity, in the sentences that follow. The use of irony increases here, bringing readers to even bigger smiles which also contain, though - as only truly successful ironic rhetoric can - a bitter-sweet call for urgent reflecting and rethinking. 
Not content with the so-called subjugation of every terrestrial bog, rock, and moorland, he would fain discover some method of reclamation applicable to the ocean and the sky, that in due calendar time they might be brought to bud and blossom as the rose. Our efforts are of no avail when we seek to turn his attention to wild roses, or to the fact that both ocean and sky are already about as rosy as possible - the one with stars, the other with dulse, and foam, and wild light. ${ }^{4}$

How to maintain this mocking tone in Italian? My strategy has been that of putting emphasis into what could appear as details, but are actually fundamental components of irony here, such as the archaic and elegant adverb "fain," which I rendered in Italian as the more common "con grande piacere" "with great pleasure"), since I could not find an equivalent adverb. While rendering "fain" as "with pleasure" would have been enough in strict terms of sheer meaning equivalency, adding "great" allows me to convey the ironic tone of the original adverb by emphasizing the absurdity inherent to feeling this pleasure: in the translation, it is now in the adjective "great" that Muir's sarcasm lies. I also gave particular attention to the translation of another expression that in the original evoked much sarcasm: "in due calendar time." Again, no perfect equivalent exists in Italian, but my expression "in tempo utile" (literally, "in useful time") aims to underline the utilitarianism intrinsic to the stiff perspective of profit invoked by Muir's original words.

The lyrical vein that emerges from Muir's texts is a crucial component of his style, and it should not be avoided or diminished in translation. "Mountain Thoughts," jotted by Muir in his journal during the 1870s but not published until $1938,{ }^{5}$ is a piece that requires a real, sustained poetic inspiration and afflatus, while translating:

Here is calm so deep, grasses cease waving... Wonderful how completely everything in wild nature fits into us, as if truly part and parent of us. The sun shines not on us but in us. The rivers flow not past, but through us, thrilling, tingling, vibrating every fiber and cell of the substance of our bodies, making them glide and sing. The trees wave and the flowers bloom in our bodies as well

\footnotetext{
4 "Wild Wool" first appeared in 1875 in the Overland Monthly and was then included in Steep Trails (Boston: Houghton Mifflin, 1915).

5 The piece appeared in fact for the first time in Linnie Marsh Wolfe's 1938 book (see above) that collected the contents of Muir's unpublished journals.
} 
as our souls, and every bird song, wind song, and tremendous storm song of the rocks in the heart of the mountains is our song, our very own, and sings our love.

The Whitmanian consonances here are striking, not only thematically but also stylistically, with Muir giving attention to repetition and alliteration and to the sheer phonic value of words, in perfect meta-textual harmony with the idea of the correspondence between an individual song and nature's larger song which is described in the passage. The language employed by Muir here in fact goes well beyond describing: language becomes the song. And Muir also uses a typical strategy employed by Whitman: that of accumulating lines that are very similar to each other and that powerfully culminate into a climax-line that is, instead, quite different from them, and that has the function to reveal, uncover, surprise. "The sun shines not [...] the rivers flow not [...] the trees wave and the flowers bloom [...]" are all descriptive lines in which the sun, the rivers, the trees do (or do not do) something, prepare for something, while, at last, "every bird song [...] is our song": the verb "to be" finally appears, emerging in all its certainty from the previous list of actions, and finally giving a full, finite expression to the existence of the song, which is the real, incarnate result of the previous lines. In my translation, I attempted to retain the alliterations, sonorous words, and accumulating rhythm:

Qui vi è una calma talmente profonda che l'erba smette di oscillare... Meraviglioso come tutto nella natura selvaggia ci calzi a pennello, come se fosse davvero una nostra parte progenitrice. Il sole scintilla non su di noi ma in noi. I fiumi scorrono non oltre noi, ma attraverso noi, tremando, titillando, facendo vibrare ciascuna fibra e cellula delle sostanze dei nostri corpi, facendoli volteggiare e cantare. Gli alberi oscillano e i fiori sbocciano nei nostri corpi come nelle nostre anime, e ogni canto di uccello e di vento e ogni terribile canto del temporale tra le rocce nel cuore delle montagne è il nostro canto, il nostro vero canto, e canta il nostro amore.

I maintained alliteration when possible: "part and parent" became "parte progenitrice," literally "progenitor part" - a considerable change, due to the fact that "parent" would have literally been "genitore," and that retaining the original conjunction would have impeded the phrase clarity in Italian. While "progenitrice" is a longer, more elevated and more intricate-sounding word than "parent," I still chose it, as it allowed me to retain the alliterating sound, 
which remained my set priority for this passage. "The sun shines" became "il sole scintilla" (literally, "the sun sparkles"). I also kept the sonorous value of the verbs used in the original by choosing "tremando, titillando" ("shaking, titillate"). In general, I opted for words and punctuation that would convey a sense of flowing, until the final stop created by "our song, our very own": "il nostro canto, il nostro vero canto" (literally "our song, our very own song," as not repeating "song" in Italian would have created confusion, unless it was replaced by a pronoun which would have been adequate for prose but not for these poetic lines).

Muir's creative ambition of transmitting into human words the message contained in the song of nature is well exemplified in these lines, also taken from "Mountain Thoughts":

Beside the grand history of the glaciers and their own, the mountain streams sing the history of every avalanche or earthquake and of snow, all easily recognized by the human ear, and every word evoked by the falling leaf and drinking deer, beside a thousand other facts so small and spoken by the stream in so low a voice the human ear cannot hear them. Thus every event is written and spoken. The wing scars the sky, making a path inevitably as the deer in snow, and the winds all know it and tell it though we hear it not.

Which I rendered as follows:

Oltre alla loro grande storia e a quella dei ghiacciai, i ruscelli di montagna cantano la storia di ogni valanga e terremoto e nevicata, tutti facilmente riconoscibili per l'orecchio umano, e pure ogni parola evocata dalla foglia che cade e dal cervo che si abbevera, insieme ad un migliaio di altri fatti talmente piccoli e sussurrati dal ruscello con una voce così bassa che l'orecchio umano non può udirli. Così ogni evento è scritto e detto. L'ala sfregia il cielo, formando inevitabilmente un percorso tracciato così come fa un cervo sulla neve, e i venti tutti lo sanno e lo dicono anche se noi non lo udiamo.

I translated this passage particularly literally, following closely the long and complex (and a bit unclear) first sentence of the original, only adding the adverb "pure" ("too") in "e pure ogni parola" (for "and every word", thus literally rendering it as "and every word too") for clarity. I also retained the word order for "the winds all know it" (perfectly equivalent to my "i venti tutti lo sanno"), aiming to keep the emphasis on the sense of totality of the winds involved: 
the Italian language would have in fact, just as the English, naturally preferred the more common "tutti i venti lo sanno," "all winds know it." Literalness, which is often, in general, an effective strategy to render poetry, as it can allow for closely mimicking unusual syntactic and vocabulary choices that create a poetic effect, is particularly adequate to convey the sense of great fascination and ultimate mystery that derives from confronting nature's message, evoked by Muir in this passage.

But opting for literalness is not always a good choice. Ironically enough, while Muir spent years trying to render wildness' essence, its intrinsic harmony, organization and perfect "civilization" 6 for readers, helping them perceive how, in nature "every event is written and spoken," I, as his translator, spent weeks deciding how to translate that very word: "wildness." Given that the Italian language did not offer an easy, perfect equivalent, I started to look for solutions. ${ }^{7}$ The main problem I had to confront was strictly cultural: not surprisingly, Italian language does not have a perfect equivalent because Italian culture does not have a similar concept. The lack of this concept in Italy is clearly described by Franco Brevini, even if with reference to the slightly different term "wilderness": ${ }^{8}$

for us [Italian people] agriculture and the centuries-old anthropization of our territory had the effect of never putting the natural landscape in such a drastic and irreconcilable contrast with the urban landscape. The United States [is] a country

${ }^{6}$ Muir insists in fact, all throughout his work, on the idea that the dichotomy between culture and nature is artificial and misleading, showing how fine and balanced nature's system and functioning are.

${ }^{7}$ I want to thank a series of colleague scholars and friends: Mario Corona, Alice Ragni, and Nicola Zito, for having patiently discussed the various possibilities of translating "wildness" into Italian with me; Kevin McMullen, not only for helping me with the idea of "wildness," but also for assisting me throughout my work on Muir and helping solve my doubts with both his insightful linguistic sensibility as a native English speaker and profound competence about nineteenth century American language and culture.

${ }^{8}$ As also explained by Brevini, the term "wildness" invokes a larger, more abstractly philosophical entity than "wilderness." For Brevini, "wildness" is in fact "that which is originally wild, that which, in its frightening transcendence, lives totally independently and autonomously from the observer," while "wilderness" is a "wild world always in opposition to the civilized world [...] [so it is] a category that strongly depends on the observer." (trans. C.B.). See Brevini: 18-19. 
grown through the gradual colonization of gigantic areas that had remained until then in a complete wild state.

(see Brevini: 231; trans. C.B.)

The choice of not translating "wildness" (or "wilderness") at all and leaving it in original English all throughout the essays, accompanied at first by a footnote that would explain the concept and why we do not have an exact equivalent in Italian, was definitely a reasonable option, but I decided to resort to it only if, by the end of my reflections and search, I would not have found something that pleased me better. Rendering it in different ways each time, depending on the context, without assigning it always the same, fixed term as an Italian correspondent, is another solution that the two other Italian translators of Muir (Paola Mazzarelli and Francesca Frulla) have opted for (although Frulla only has to work with "wilderness," as "wildness" never appears in A Thousand-Mile Walk). ${ }^{9}$ This approach, however, I did not agree with, as it seemed to disperse the original density of meaning of the concept into a myriad of slightly different ideas. Is it really not possible, I asked myself, to come at least close to "wildness," and to do what Umberto Eco called, in a cogent definition of translation itself as an activity, "to say almost the same thing"? (see Eco, 2003) ${ }^{10}$ When reflecting about terms that would at least come close to being equivalents in Italian, and manage to well, if not perfectly, render "wildness," "selvaticità" and "selvatichezza" both emerged. The adjective "selvatico," at the base of both nouns "selvaticità" and "selvatichezza," originates in the latin silva (woods), silvaticus (belonging to the woods), and indicates an uncultivated plant or untamed animal. But the nouns, which sound unusual and almost made-up in Italian as they are not commonly used, would seem

\footnotetext{
9 Mazzarelli translates wildness as "selvatica distesa" ("savage expanse") on page 78, "perfetta solitudine" ("perfect loneliness") on page 165, "natura selvaggia" ("wild nature") on page 115 and "selvaggia libertà" ("wild freedom") on page 296. Frulla translates "wilderness" as "natura incontaminata" ("uncontaminated nature") on page 8 and 10, "natura selvaggia" ("wild nature") on page 50, "luogo selvaggio" ("wild place") on page 81, and "regioni selvagge" ("wild regions") on page 151.

10 Eco's book, together with Lawrence Venuti's various books on translation, such as The Translator's Invisibility (1995) and Translation Changes Everything (2013) have strongly influenced my practices and strategies, not only in this particular case, but more largely for my translating work during the last years.
} 
to mean mostly "roughness" or "savageness," and to indicate characteristics of somebody's personality or of particular life conditions. I then considered "stato di natura" ("state of nature"), but dismissed it soon enough for its too highly philosophical connotation and for how limiting the idea of a particular "state" can sound, in the text.

But pausing on "state of nature" helped me understand that, in Italian, the idea of "nature" had to be retained: if we lack an idea of wildness, Italian and pre-Italian literary traditions have definitely considered and discussed nature and natural things; let us only think of Virgil's Bucolics, Lucretius' De Rerum Natura and Giacomo Leopardi's reasoning about nature in his poetry and also in his essays and treatises. And it is to "nature" that we would refer to when talking about that part of our world that has been left intact and not urbanized or modified, or at least not fully. So, I then decided that I could just add to "natura" the adjective "selvaggia" and then have what in English would sound like "wild nature," which seemed to me to be close enough. Only after having chosen this did I happily learn that the concept of "natura selvaggia" has been recently used, following the heightened attention given to environmentalist matters in the last years, by the above-cited Brevini in his study dedicated to this concept, but also by other scholars, like Massimo Centini and Remo Bodei (see Bodei, 2013; Centini, 2013). I also then noticed how both Mazzarelli and Frulla opted for "natura selvaggia," although not always, as they rendered the term in different ways depending on the context, as I indicated above.

All these discoveries gave me a certain peace of mind, indeed a highly desirable state for a translator who hopes to step not too heavily across the flexible borders that exist between languages and cultures. I then resolved to adopt "natura selvaggia" throughout my translation, any time "wildness" is used, and to have instead "territori selvaggi" ("wild territories") for "wilderness," to indicate a more tangible idea of un-colonized, uncontaminated space.

Hopefully, apart from these vocabulary disquisitions and strategies of linguistic mediation, Italian readers will get to enjoy Muir's own successful attempt to render wildness by making us experience the same feelings of awe, admiration and protectiveness for nature's beauty and perfection that he encountered in his own musings and wanderings about one hundred and fifty years ago. For, as he puts it, 
Nothing is more wonderful than to find smooth harmony in this lofty cragged region where at first sight all seems so rough. From any of the high standpoints a thousand peaks, pinnacles, spires are seen thrust into the sky and so sheer and bare as to be inaccessible to wild sheep, accessible only to the eagle. Any one by itself harsh, rugged, crumbling, yet in connection with others seems like a line of writing along the sky; it melts into melody, one leading into another, keeping rhythm in time.

But, more importantly, hopefully readers will accept the somewhat paradoxical (and very Whitmanian) invitation by Muir's to stop reading and getting out, into wildness, to experience it for themselves and not, in Whitman's words, "take things at second or third hand," 11 having understood that Muir's words and books can only be a faint introduction to natural wonders:

No amount of word-making will ever make a single soul to know these mountains. As well seek to warm the naked and frostbitten by lectures on caloric and pictures of flame. One day's exposure to mountains is better than cartloads of books. ${ }^{12}$

\section{Works Cited}

Bodei, Remo. Paesaggi sublimi: gli uomini davanti alla natura selvaggia. Milano: Bompiani, 2013.

Brevini, Franco. L'invenzione della natura selvaggia. Storia di un'idea dal XVIII secolo a oggi. Torino: Bollati Boringhieri, 2013.

Centini, Massimo. La wilderness: la natura selvaggia e l'uomo. Milano: Xenia, 2013.

Dostoevsky, Fyodor. The Idiot [1869]. https://www.gutenberg.org/files/2638/2638h/2638-h.htm [accessed: 13.03.2019].

Eco, Umberto. Dire quasi la stessa cosa. Milano: Bompiani, 2003.

John of the Mountains: The Unpublished Journals of John Muir [1938]. Ed. Linnie Marsh Wolfe. Madison: University of Wisconsin Press, 1979.

${ }^{11}$ Here I am quoting from Walt Whitman's section two of "Song of Myself," available online on the Walt Whitman Archive at https://whitmanarchive.org/published/LG/1891/whole.html.

${ }_{12}$ Both these excerpts are taken from Muir's "Mountain Thoughts." 
Muir, John. A Thousand-Mile Walk to the Gulf. Boston: Houghton Mifflin, 1916. https:// vault.sierraclub.org/john_muir_exhibit/writings/a_thousand_mile_walk_to_the_ gulf [accessed: 13.03.2019].

-----. La mia prima estate sulla sierra [My First Summer in the Sierra (1911)]. Trans. Paola Mazzarelli. Torino: Vivalda, 1995.

-----. Mille miglia in cammino fino al golfo del Messico [A Thousand-Mile Walk to the Gulf (1916)]. Trans. Francesca Frulla. Roma: Edizioni dei Cammini, 2015.

-----. Our National Parks. Boston: Houghton Mifflin, 1901.

-----. The Mountains of California. New York: Century, 1894.

-----. Travels in Alaska. Boston: Houghton Mifflin, 1915.

-----. “Wild Wool." Overland Monthly, 1875. https://vault.sierraclub.org/john_muir_ exhibit/writings/wild_wool.aspx [accessed: 13.03.2019].

The Life and Letters of John Muir. Ed. William Frederic Badè. Boston: Houghton Mifflin, 1924.

Thoreau, Henry David. "Walking” [1862]. http://www.gutenberg.org/files/1022/1022h/1022-h.htm [accessed: 13.03.2019].

Venuti, Lawrence. The Translator's Invisibility. London: Routledge, 1995.

-----. Translation Changes Everything. London: Routledge, 2013.

Wilkins, Thurman. John Muir: Apostle of Nature. Norman: University of Oklahoma Press, 1995.

Whitman, Walt. Leaves of Grass [1891-1892]. https://whitmanarchive.org/published/ LG/1891/whole.html [accessed: 13.03.2019].

\section{On Rendering Wildness: Choices and Strategies for Translating John Muir's Essays into Italian}

\section{Summary}

This essay treats the Italian translation of a selection of essays taken from a series of books by American naturalist writer John Muir (1838-1914). The translator considers the peculiarities of Muir's style and themes and describes the strategies she used in order to render his writing into Italian. In particular, the translator discusses, by using 
excerpts from the texts as examples, Muir's complex syntax, use of archaisms and accumulative style, the continual presence of irony and of a strong metaphysical and poetic vein (much consonant with Walt Whitman's poetry). Much attention is given to the issue of translating the term "wildness," due to the difficulty of finding an equivalent expression in Italian.

Keywords: comparative literature, translation strategies, John Muir, wildness, nature, Walt Whitman

Słowa kluczowe: literatura porównawcza, strategie translatorskie, John Muir, dzikość, natura, Walt Whitman 